\title{
Formation of highly oxygenated organic molecules from aromatic compounds
}

\author{
Ugo Molteni ${ }^{1}$, Federico Bianchi ${ }^{2}$, Felix Klein ${ }^{1}$, Imad El Haddad ${ }^{1}$, Carla Frege ${ }^{1}$, Michel J. Rossi ${ }^{1}$, Josef Dommen ${ }^{1}$, and \\ Urs Baltensperger ${ }^{1}$ \\ ${ }^{1}$ Laboratory of Atmospheric Chemistry, Paul Scherrer Institute, 5232 Villigen, Switzerland \\ ${ }^{2}$ Institute for Atmospheric and Earth System Research, University of Helsinki, 00014 Helsinki, Finland
}

Correspondence: Urs Baltensperger (urs.baltensperger@psi.ch)

Received: 16 December 2016 - Discussion started: 23 December 2016

Revised: 19 December 2017 - Accepted: 25 December 2017 - Published: 9 February 2018

\begin{abstract}
Anthropogenic volatile organic compounds (AVOCs) often dominate the urban atmosphere and consist to a large degree of aromatic hydrocarbons (ArHCs), such as benzene, toluene, xylenes, and trimethylbenzenes, e.g., from the handling and combustion of fuels. These compounds are important precursors for the formation of secondary organic aerosol. Here we show that the oxidation of aromatics with $\mathrm{OH}$ leads to a subsequent autoxidation chain reaction forming highly oxygenated molecules (HOMs) with an $\mathrm{O}: \mathrm{C}$ ratio of up to 1.09. This is exemplified for five single-ring ArHCs (benzene, toluene, o-/m-/p-xylene, mesitylene (1,3,5trimethylbenzene) and ethylbenzene), as well as two conjugated polycyclic ArHCs (naphthalene and biphenyl). We report the elemental composition of the HOMs and show the differences in the oxidation patterns of these ArHCs. A potential pathway for the formation of these HOMs from aromatics is presented and discussed. We hypothesize that AVOCs may contribute substantially to new particle formation events that have been detected in urban areas.
\end{abstract}

\section{Introduction}

Volatile organic compounds (VOCs) from biogenic and anthropogenic sources are the precursors of atmospheric oxidation products in the gas and particle phase. While global biogenic VOC (BVOC) emissions are a factor of 10 higher than the emissions of anthropogenic VOCs (AVOCs), the latter often dominate in the urban atmosphere (Atkinson and Arey, 2003). It has been shown recently that atmospheric oxidation products of BVOCs, such as the monoterpene alpha-pinene, include highly oxygenated molecules (HOMs) through an autoxidation mechanism (Crounse et al., 2012, 2013; Ehn et al., 2014). The first step is a reaction of either $\mathrm{OH}$ free radicals or ozone with the VOC. After the addition of $\mathrm{O}_{2}$ to the carbon-centered radical site, the $\mathrm{RO}_{2} \cdot$ radical can isomerize by intramolecular hydrogen abstraction to form a new carbon-centered radical (QOOH) (Crounse et al., 2012, 2013; Ehn et al., 2014). Further $\mathrm{O}_{2}$ addition and isomerization sequences result in HOMs bearing several hydroperoxy groups. This autoxidation mechanism is supported by various experimental studies which used biogenic precursors, i.e., monoterpenes, sesquiterpenes, isoprene, and structural surrogates of these, and computer simulations (Berndt et al., 2015; Jokinen et al., 2014, 2015; Kurtén et al., 2015; Mentel et al., 2015; Praplan et al., 2015; Richters et al., 2016; Rissanen et al., 2014, 2015). HOMs of these compounds were found to initiate new particle formation and substantially contribute to early particle growth, which is important for the survival of newly formed particles and their ability to form cloud condensation nuclei (CCN; Bianchi et al., 2016; Kirkby et al., 2016; Tröstl et al., 2016). CCN can impact climate via their influence on cloud properties; this changes the present-day radiation balance and changed it even more in the preindustrial period (Carslaw et al., 2013; Gordon et al., 2016).

AVOCs are comprised of a high fraction of aromatic hydrocarbons (ArHCs), such as benzene, toluene, xylenes, and trimethylbenzenes, which are released from the handling and combustion of fuels (Atkinson and Arey, 2003) and are important precursors for the formation of secondary organic aerosol (SOA) (Bruns et al., 2016; Li et al., 2016; Metzger et al., 2010). The $\mathrm{OH}$ radical is the preponderant atmospheric 
oxidant for ArHC except for phenols or substituted ArHC with nonaromatic double bonds where ozone and the $\mathrm{NO}_{3}$ radical play a relevant role (Calvert et al., 2002). The addition of the $\mathrm{OH}$ radical to the aromatic ring results in the formation of a hydroxycyclohexadienyl-type radical (Bohn, 2001; Molina et al., 1999). Under atmospheric conditions this reacts with $\mathrm{O}_{2}$ to yield peroxy radicals or phenolic compounds (Calvert et al., 2002; Glowacki and Pilling, 2010; Suh et al., 2003). When aromaticity is lost by $\mathrm{OH}$ addition, nonaromatic double bonds are formed representing highly reactive products to more oxidants, which is a peculiar behavior not observed in other classes of VOCs (Calvert et al., 2002), This behavior makes the investigation of ArHC oxidation more complex.

Here we show the formation of HOMs from various ArHCs upon reaction with $\mathrm{OH}$ radicals. A similar conclusion was reported nearly simultaneously by Wang et al. (2017), while our paper was under review. We present product distributions of HOMs in terms of molecular masses and molecular formulas for a series of aromatic precursors based on measurements with a nitrate chemical ionization atmospheric pressure interface time of flight mass spectrometer (CI-APiTOF) (Ehn et al., 2014; Jokinen et al., 2012; Kürten et al., 2011). A potential pathway along with a possible mechanism for the formation of HOMs from aromatic compounds is discussed.

\section{Experimental section}

\subsection{Flow tube}

Five single-ring ArHCs - benzene (Merck, $\geq 99.7 \%$ ), toluene (VWR Chemicals, $\geq 99.6 \%$ ), a mixture of o$/ \mathrm{m}$-/p-xylene isomers (Merck, 96\%), mesitylene $(1,3,5$ trimethylbenzene) (Fluka, $\sim 99 \%$ ), and ethylbenzene (Fluka, > 99\%) - and two polycyclic ArHCs - naphthalene (Fluka, $\geq 99 \%$, solid) and biphenyl (Sigma-Aldrich, $\geq$ $98 \%$, solid) - were investigated in a flow tube (Table 1). The experimental setup is shown in Fig. 1. Zero air from a pure-air generator (Aadco Instruments, Inc., Cleves $\mathrm{OH}$, USA) was used. A $104 \mathrm{~cm}$ long Pyrex glass tube of $7.4 \mathrm{~cm}$ diameter described previously (Pratte and Rossi, 2006) was used as a flow tube. Vapors of the aromatic compounds were generated from a glass vial and collected by a stream of zero air $\left(1.1 \mathrm{~L} \mathrm{~min}^{-1}\right)$ via a glass capillary for liquid compounds (and from a flask flushed with the same stream of zero air for solid compounds). To generate $\mathrm{OH}$ free radicals, zero air $\left(7 \mathrm{~L} \mathrm{~min}{ }^{-1}\right.$ ) was passed through a Nafion humidifier (Perma Pure) fed with ultrapure water and was then irradiated by an excimer lamp at $172 \mathrm{~nm}(7.2 \mathrm{eV})$ (Kogelschatz, 1990, 2012; Salvermoser et al., 2008). The Xe excimer lamp consists of a tubular quartz cell which surrounds a quartz flow tube (outer diameter $10 \mathrm{~mm}$ ) (Bartels-Rausch et al., 2011). This light photolyzes $\mathrm{O}_{2}$ and $\mathrm{H}_{2} \mathrm{O}$ leading to the formation of $\mathrm{OH}$ and $\mathrm{HO}_{2}$ radicals (see Sect. $\mathrm{S} 1$ in the Supplement). Subsequently, the airstream with the $\mathrm{OH}$ free radicals was combined at an angle of $90^{\circ}$ with the reagent flow containing the aromatic vapors before entering the flow tube, initiating the oxidation reaction. This experimental setup avoids any potential bias due to exposure of ArHC vapors to UV radiation (Jain et al., 2012; Peng et al., 2016). This mixture (total $8.1 \mathrm{~L} \mathrm{~min}^{-1}$ ) was injected into a laminar sheath flow of $6.7 \mathrm{~L} \mathrm{~min}^{-1}$ zero air at the inlet of the flow tube. The residence time in the flow tube was $20 \mathrm{~s}$. All experiments were performed at $25^{\circ} \mathrm{C}$. A description of the chemical reactions involved in the excimer lamp $\mathrm{OH}$ radical production and a flow tube kinetic model for the mesitylene oxidation are given in Sect. S1.

\subsection{Instruments}

The concentrations of the ArHC precursors and D9-butanol as an $\mathrm{OH}$ tracer (Barmet et al., 2012) were measured at the exit of the flow tube with a proton transfer reaction time of flight mass spectrometer (PTR-TOF-MS) (Jordan et al., 2009) when the excimer lamp to generate $\mathrm{OH}$ free radicals was switched off and on. A nitrate chemical ionization atmospheric pressure interface time of flight mass spectrometer (CI-APi-TOF) (Ehn et al., 2014; Jokinen et al., 2012; Kürten et al., 2011) measured the chemical composition of the HOMs that were formed via $\mathrm{OH}$ free radical oxidation of the aromatics. HOMs were detected either through acid-base reaction or adduct formation with a nitrate ion according to the following scheme:

$$
\begin{aligned}
& \mathrm{HOM}+\mathrm{NO}_{3}^{-} \cdot\left(\mathrm{HNO}_{3}\right)_{n} \rightarrow \mathrm{HOM} \cdot \mathrm{NO}_{3}^{-}+n \mathrm{HNO}_{3} \\
& \quad n=0-2, \\
& \mathrm{HOM}+\mathrm{NO}_{3}^{-} \cdot\left(\mathrm{HNO}_{3}\right)_{n} \rightarrow \mathrm{HOM}^{-}+(n+1) \mathrm{HNO}_{3} \\
& \quad n=0-2 .
\end{aligned}
$$

Trifluoroacetic acid (monomer and dimer) was detected as a major contaminant in the CI-APi-TOF spectra. We identified the Nafion humidifier membrane as the source of fluorinated organic compounds.

HOM yields are calculated as the ratio of HOMs measured to ArHC reacted. HOMs were quantified using the calibration factor for sulfuric acid and assuming the same charging efficiency for HOMs (Ehn et al., 2014; Kirkby et al., 2016). From the decrease in the precursor concentration (lights off versus lights on) of D9-butanol, toluene, mesitylene, and biphenyl, we determined the fraction of reacted precursor. With a kinetic reaction model we then determined the initial $\mathrm{OH}$ concentration to be around $8.5 \times 10^{11} \mathrm{~cm}^{-3}$ (Sect. S1 in the Supplement). For the other precursors we assumed the same $\mathrm{OH}$ production of the lamp to calculate the fraction of reacted precursors (Table 1). Ozone, produced in the excimer irradiated region as a side product of the $\mathrm{OH}$ generation, was measured to be about $140 \mathrm{ppbv}$ at the exit of the flow tube. It does not react with aromatic compounds. Even though some 


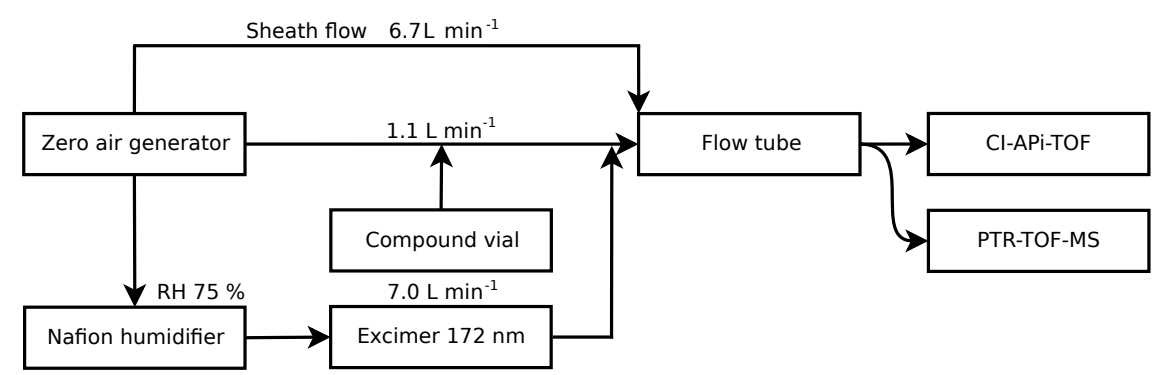

Figure 1. Experimental setup. Zero air from a pure-air generator is split into three flows. There is a sheath flow of $6.7 \mathrm{~L} \mathrm{~min}{ }^{-1}$. An airstream of $1.1 \mathrm{~L} \mathrm{~min}^{-1}$ collects vapors from a reagent compound vial and is then mixed with a humidified airstream of $7 \mathrm{~L} \mathrm{~min}{ }^{-1}(\mathrm{RH} 75 \%)$ which carries $\mathrm{OH}$ free radicals generated through irradiation at $172 \mathrm{~nm}$.

Table 1. Initial concentrations of precursors, reaction rate coefficients, ArHC reacted fraction (\%), total HOM concentration, and HOM yield (\%) relative to the reacted ArHC. The concentration of precursors was determined at the exit of the flow tube when the excimer lamp (OH generation) was switched off.

\begin{tabular}{|c|c|c|c|c|c|}
\hline Compound & $\begin{array}{l}\text { Concentration } \\
\text { (molecules } \mathrm{cm}^{-3} \text { ) }\end{array}$ & $\begin{array}{c}k_{\mathrm{OH}} \\
\left(10^{-12} \mathrm{~cm}^{3} \text { molecules }^{-1} \mathrm{~s}^{-1}\right)\end{array}$ & $\begin{array}{c}\text { Reacted fraction } \\
(\%)\end{array}$ & $\begin{array}{c}{[\mathrm{HOM}]} \\
\left(\text { molecules cm } \mathrm{cm}^{-3} \text { ) }\right.\end{array}$ & $\begin{array}{l}\text { HOM yield } \\
(\%)\end{array}$ \\
\hline Benzene $\left(\mathrm{C}_{6} \mathrm{H}_{6}\right)$ & $9.85 \times 10^{13}$ & 1.22 & 0.5 & $1.2 \times 10^{9}$ & 0.2 \\
\hline Toluene $\left(\mathrm{C}_{7} \mathrm{H}_{8}\right)$ & $1.97 \times 10^{13}$ & 5.63 & 2.3 & $4.4 \times 10^{8}$ & 0.1 \\
\hline Ethylbenzene $\left(\mathrm{C}_{8} \mathrm{H}_{10}\right)$ & $1.13 \times 10^{13}$ & 7.0 & 4.4 & $9.4 \times 10^{8}$ & 0.2 \\
\hline$(\mathrm{o} / \mathrm{m} / \mathrm{p})$-Xylene $\left(\mathrm{C}_{8} \mathrm{H}_{10}\right)$ & $2.95 \times 10^{12}$ & $13.6 / 23.1 / 14.3$ & $5.4-9.2$ & $2.8 \times 10^{9}$ & $1.0-1.7$ \\
\hline Mesitylene $\left(\mathrm{C}_{9} \mathrm{H}_{12}\right)$ & $2.46 \times 10^{12}$ & 56.7 & 22.7 & $3.1 \times 10^{9}$ & 0.6 \\
\hline Naphthalene $\left(\mathrm{C}_{10} \mathrm{H}_{8}\right)$ & $2.95 \times 10^{13}$ & 23.0 & 2.6 & $1.4 \times 10^{10}$ & 1.8 \\
\hline Biphenyl $\left(\mathrm{C}_{12} \mathrm{H}_{10}\right)$ & $4.43 \times 10^{13}$ & 7.1 & 1.6 & $1.8 \times 10^{10}$ & 2.5 \\
\hline
\end{tabular}

Reference for $k$ : Atkinson and Arey (2003).

$\mathrm{OH}$ oxidation products will contain a $\mathrm{C}=\mathrm{C}$ double bond, the slow reaction rate of these with ozone is not expected to form significant amounts of products via this route.

\section{Results and discussion}

\subsection{Comparison of HOMs from different ArHC}

The oxidation products of the $\mathrm{OH}$ reaction with each of the five single-ring and two polycyclic ArHCs were measured at the exit of the tube using the CI-APi-TOF. Table 1 lists the initial concentrations and the corresponding reaction rate constants with the $\mathrm{OH}$ radical, the reacted fractions $(\%)$, the HOM concentrations, and the HOM yields (\%) calculated based on the reacted precursor concentrations. All investigated compounds yielded HOMs in a range between 0.1 and $2.5 \%$ of the reacted ArHC. They were detected either as adducts with a nitrate ion $\left(\mathrm{NO}_{3}^{-}\right)$or as de-protonated ions. Section S2 in the Supplement presents HOM peak lists for all the ArHC compounds: for each compound we report the largest $n$ peaks that sum up to $80 \%$ of the total detected signal of HOMs. Figure 2 displays the mass spectra obtained from the monocyclic aromatics. In the mass-to-charge $(\mathrm{m} / \mathrm{z})$ range $130-365$ thomson $\left(\mathrm{Th} ; 1 \mathrm{Th}=1 \mathrm{Da} e^{-1}\right.$, where $e$ is the elementary charge), the oxidation products contain the carbon skeleton of the precursor (monomer region), while in the $m / z$ range 285-540 Th the number of carbon atoms is doubled (dimer region). The lower end of the peak sequence (which for the benzene experiment corresponds to the oxidation product with the formula $\mathrm{C}_{6} \mathrm{H}_{6} \mathrm{O}_{5}\left(\mathrm{NO}_{3}\right)^{-}$) is shifted by differences of $14 \mathrm{Th}\left(\mathrm{CH}_{2}\right)$ each from benzene via toluene and xylene/ethylbenzene to mesitylene due to the additional substituent groups. In general, a series of peaks with a mass difference of two oxygen atoms can be seen in the monomer as well as the dimer region. At each oxygen addition a few peaks are observed because oxidation compounds with the same carbon and oxygen number but different hydrogen number were observed. These peaks can be attributed to closed-shell or radical compounds based on the number of hydrogen (even or odd).

HOMs from naphthalene and biphenyl are presented in Fig. 3. Monomers, dimers, trimers, and tetramers, and even pentamers for biphenyl, are observed. While some of the dimers may have been formed by $\mathrm{RO}_{2} \bullet-\mathrm{RO}_{2} \cdot$ reactions, most of the higher $n$-mers are probably bound by nonbonding interactions, similar to biogenic HOMs (Donahue et al., 2013). Clusters with $m / z \geq 800 \mathrm{Th}$ might already be detected by particle counters with a mobility diameter $d \geq$ $1.5 \mathrm{~nm}$ (Kulmala et al., 2013). 

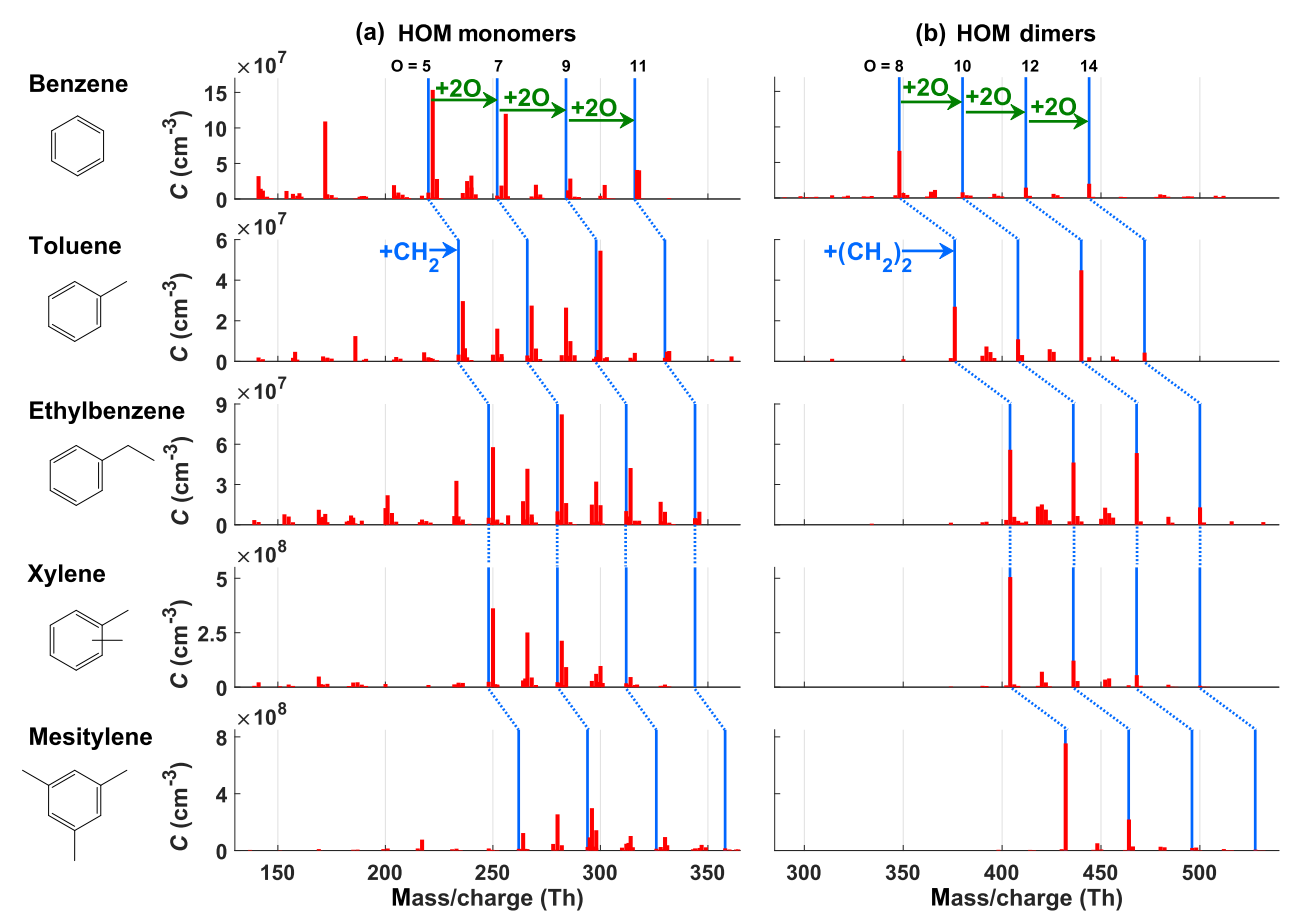

Figure 2. Mass spectra (displayed in red) of HOMs from five monocyclic ArHCs (benzene, toluene, ethylbenzene, xylenes, mesitylene). HOM monomers (a) have the same number of carbon atoms as the precursor, while HOM dimers (b) have twice as many. Green arrows in the benzene panel show a sequence of peaks separated by a mass corresponding to two oxygen atoms. This may be connected to the autoxidation mechanism which proceeds through the addition of $\mathrm{O}_{2}$ molecules. The same sequence is seen in the other ArHCs, which we have indicated by the blue dashed and solid lines to guide the eye of the reader. The initial peak and the corresponding sequence of the five single-ring ArHCs are shifted by a $\mathrm{CH}_{2}$ unit due to the different substituents (blue arrow in the toluene panel). HOMs with the same number of oxygen atoms can have a different number of hydrogen atoms $(n, n+2, n+4)$. Note the different peak intensity patterns observed for the different chemical compounds, even for xylene and ethylbenzene, i.e., molecules with the same chemical formula.

In Table 2 we summarize the general features of the peak distribution of monomers, dimers, and $n$-mers, as well their $\mathrm{O}: \mathrm{C}$ ratios. The values given in the table cannot be considered to be absolute values, since we do not know the transmission function of the mass spectrometer. Thus, the true dimer / monomer ratio might be different. However, since the mass-dependent ion transmission efficiency is rather smooth, the values given may faithfully represent the relative product distribution of the different aromatic compounds. Most of the identified peaks (77-94\%) were detected as adduct with $\mathrm{NO}_{3}^{-}$. The integrated signal intensity in the monomer region makes up 61 to $80 \%$ of the total detected ArHC product signal for the monocyclic ArHCs and 34-52\% for the double-ring compounds. A further analysis of HOMs from monocyclic ArHC shows an increase in the dimer fraction, which coincides with an increase in the methyl/ethyl substituents as follows: benzene (20\%), toluene (29\%), ethylbenzene $(31 \%)$, xylene $(35 \%)$, and mesitylene $(39 \%)$. This indicates that the branching ratio of $\mathrm{RO}_{2} \bullet+\mathrm{RO}_{2} \cdot$ to dimer (Reaction R3c) compared to the other reaction channels (Reactions R3a, R3b) is higher for the more substituted aromatics. This is based on the assumption that the lamp produces similar concentrations of $\mathrm{OH}$ and $\mathrm{HO}_{2}$ radicals and that the reaction rate coefficients $k\left(\mathrm{RO}_{2} \bullet+\mathrm{HO}_{2} \bullet\right)$ (Reaction $\left.\mathrm{R} 4 \mathrm{a}\right)$ are similar for all $\mathrm{RO}_{2} \cdot$. Monomers as well as dimers are highly oxygenated, even though the oxygen-to-carbon $(\mathrm{O}: \mathrm{C})$ ratio is 20-30\% higher for the monomers compared to the dimers. Single-ring ArHC monomers have on average an $\mathrm{O}: \mathrm{C}$ ratio of 0.94 ( 0.50 for the double-ring ArHC), while dimers that were generated from monocyclic ArHC have on average an $\mathrm{O}: \mathrm{C}$ ratio of 0.67 ( 0.32 for the double-ring ArHC). This may be due to the dimer formation mechanism itself, which is thought to be the formation of a peroxide $\mathrm{C}-\mathrm{O}-\mathrm{O}-\mathrm{C}$ bond which involves the elimination of molecular oxygen (Mentel et al., 2015; Wallington et al., 1992). Additionally, more oxygenated radicals have a higher probability of undergoing an unimolecular termination compared to a radical-radical recombination $\left(\mathrm{RO}_{2} \bullet+\mathrm{RO}_{2} \bullet\right.$ or $\left.\mathrm{RO}_{2} \bullet+\mathrm{HO}_{2} \bullet\right)$. More oxygen atoms imply more peroxy functional groups and therefore a higher probability of a hydrogen abstraction in the geminal position of a peroxide, which results in an $\mathrm{OH}$ radical loss and a carbonyl group formation. Therefore, the fraction of dimer formation should decrease with a higher oxygen content of monomers. Furthermore, we assume that less oxygenated radicals, although not quantitatively detected by the CI-APi-TOF (Berndt et al., 2015; Hyttinen et al., 2015), will 

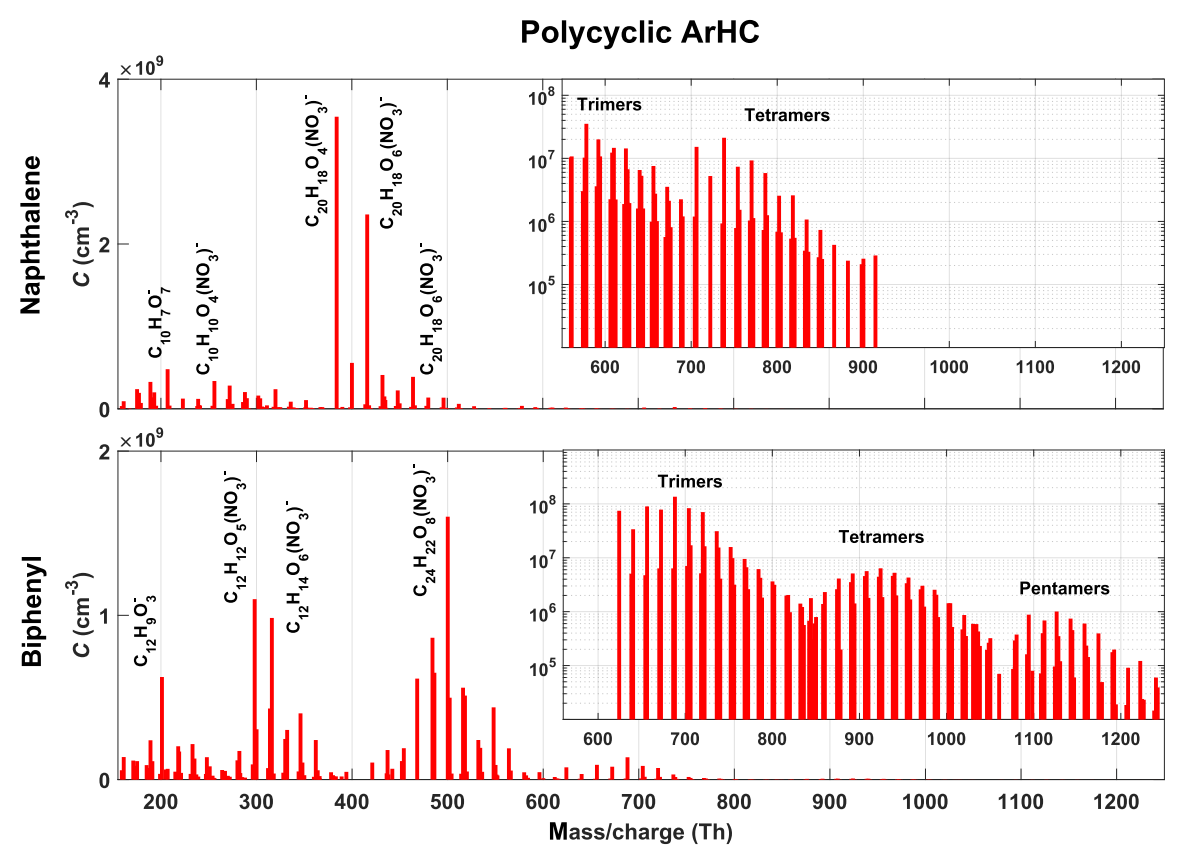

Figure 3. Mass spectra of HOMs from the bicyclic ArHCs naphthalene and biphenyl. The chemical composition of some representative peaks is displayed. Due to the high concentrations, the nitrate CI-APi-TOF was also able to detect the HOMs clusters up to the pentamer and also retrieve their chemical formula (see inserts).

nevertheless participate in the dimer formation. Substantially lower $\mathrm{O}: \mathrm{C}$ ratios are found for naphthalene and biphenyl, whereby the trend between the monomers and the dimers and higher-order clusters is the same as for the single-ring ArHCs. The lower $\mathrm{O}: \mathrm{C}$ ratio is probably owing to the fact that the second aromatic ring remains and does not allow for extensive autoxidation.

Figure 4 shows the contributions of the most abundant identified HOMs to $80 \%$ of the total signal. The chemical composition of the observed monomers, dimers, and radicals for each precursor is presented in Sect. S3 in the Supplement (Fig. S3, panels 1 to 7). It is seen that in the series benzene, toluene, xylene, and mesitylene, the number of HOMs needed to sum up $80 \%$ of the total signal decreases (except for ethylbenzene). The increasing number of methyl groups appears to influence the oxidation pathways and leads to less HOM products. Ethylbenzene shows the highest number of HOMs. These also include monomers with seven carbon atoms as well as dimers with an unexpectedly low number of hydrogen atoms (20 instead of 22) (Fig. S3, panel 3). This could indicate the occurrence of different pathways due to the ethyl group, a chemistry less bounded by the aromatic ring, which implies an initial hydrogen abstraction step by the $\mathrm{OH}$ radical. Together with ethylbenzene, benzene and naphthalene, the two tested and unsubstituted ArHCs also present dimers with an unexpectedly low hydrogen number (12 instead of 14 and 16 instead of 18). Biphenyl also shows an unexpectedly low number of hydrogen atoms for some of the HOM monomers detected. This feature, highlighted in the four abovementioned compounds, turns out to be a minority in terms of peaks detected and relative peak intensity.

\subsection{ArHC HOM formation mechanism}

A generalized mechanism that may explain the formation of these highly oxygenated compounds from $\mathrm{ArHCs}$ by $\mathrm{OH}$ addition is exemplified for mesitylene in Fig. 5. This mechanism is also applicable to the other ArHCs tested. An $\mathrm{OH}$ free radical attack on alkyl-substituted arenes is thought to either abstract a hydrogen atom from an $\mathrm{sp}^{3}$ hybridized carbon or to add to the aromatic ring. Starting from a generic aromatic compound with the formula $\mathrm{C}_{x} \mathrm{H}_{y}$, hydrogen abstraction results in a $\mathrm{C}_{x} \mathrm{H}_{y-1}$ radical, while $\mathrm{OH}$ addition results in a radical with the formula $\mathrm{C}_{x} \mathrm{H}_{y+1} \mathrm{O}_{1}$. If we allow both initial intermediate products to proceed via autoxidation by the formal addition of $\mathrm{O}_{2}$, we expect radicals with the composition $\mathrm{C}_{x} \mathrm{H}_{y-1} \mathrm{O}_{z_{\mathrm{e}}}$ (initial hydrogen abstraction) and $\mathrm{C}_{x} \mathrm{H}_{y+1} \mathrm{O}_{z_{0}}$ (initial $\mathrm{OH}$ addition) to be formed, where $z$ denotes any number of oxygen atoms - an even number $\left(z_{\mathrm{e}}\right)$ in the former case and an odd number $\left(z_{\mathrm{o}}\right)$ in the latter case. This addition of molecular $\mathrm{O}_{2}$ increases the mass of the compounds by $32 \mathrm{Da}$ resulting in the propagation of a radical with an odd number of oxygen atoms. This can be seen by $m / z$ shifts of 32 Th in the mass spectra. For the ArHCs tested we do not observe radicals with the formula $\mathrm{C}_{x} \mathrm{H}_{y-1} \mathrm{O}_{z_{\mathrm{e}}}$, owing to the fact that hydrogen abstraction is a minor pathway (with, e.g., a branching ratio of $7 \%$ for toluene according to 
Table 2. Summary of HOM characteristics. For each of the seven compounds the percentage fractional distribution of the signal is presented. For monocyclic compounds the distribution comprises monomers and dimers; for naphthalene and biphenyl, monomers, dimers, trimers, and tetramers are reported. These values are not quantitative as the instrument cannot be calibrated for such compounds. For each band the weighted arithmetic means of the $\mathrm{O}: \mathrm{C}$ ratio are reported in parentheses. The fraction of the identified peaks as adduct with $\mathrm{NO}_{3}^{-}$is given in the last column.

\begin{tabular}{|c|c|c|c|c|c|}
\hline \multirow[b]{2}{*}{ Compound } & \multicolumn{4}{|c|}{ Band distribution } & \multirow[b]{2}{*}{ Adduct $\left(\mathrm{HOM} \cdot \mathrm{NO}_{3}^{-}\right)$} \\
\hline & \multicolumn{2}{|c|}{ Monomer $(\mathrm{O}: \mathrm{C})$} & \multicolumn{2}{|c|}{$\operatorname{Dimer}(\mathrm{O}: \mathrm{C})$} & \\
\hline Benzene $\left(\mathrm{C}_{6} \mathrm{H}_{6}\right)$ & \multicolumn{2}{|c|}{$80(1.08)$} & \multicolumn{2}{|c|}{$20(0.91)$} & 0.91 \\
\hline Toluene $\left(\mathrm{C}_{7} \mathrm{H}_{8}\right)$ & \multicolumn{2}{|c|}{$71(1.09)$} & \multicolumn{2}{|c|}{$29(0.75)$} & 0.94 \\
\hline Ethylbenzene $\left(\mathrm{C}_{8} \mathrm{H}_{10}\right)$ & \multicolumn{2}{|c|}{$69(0.86)$} & \multicolumn{2}{|c|}{$31(0.62)$} & 0.83 \\
\hline$(\mathrm{o} / \mathrm{m} / \mathrm{p})$-Xylene $\left(\mathrm{C}_{8} \mathrm{H}_{10}\right)$ & \multicolumn{2}{|c|}{$65(0.78)$} & \multicolumn{2}{|c|}{$35(0.57)$} & 0.92 \\
\hline \multirow[t]{2}{*}{ Mesitylene $\left(\mathrm{C}_{9} \mathrm{H}_{12}\right)$} & \multicolumn{2}{|c|}{$61(0.81)$} & \multicolumn{2}{|c|}{$39(0.49)$} & 0.92 \\
\hline & Monomer $(\mathrm{O}: \mathrm{C})$ & $\operatorname{Dimer}(\mathrm{O}: \mathrm{C})$ & Trimer $(\mathrm{O}: \mathrm{C})$ & Tetram & \\
\hline Naphthalene $\left(\mathrm{C}_{10} \mathrm{H}_{8}\right)$ & $34(0.55)$ & $64(0.29)$ & $2(0.34)$ & & 0.84 \\
\hline Biphenyl $\left(\mathrm{C}_{12} \mathrm{H}_{10}\right)$ & $52(0.44)$ & $43(0.35)$ & $4(0.29)$ & & 0.77 \\
\hline
\end{tabular}

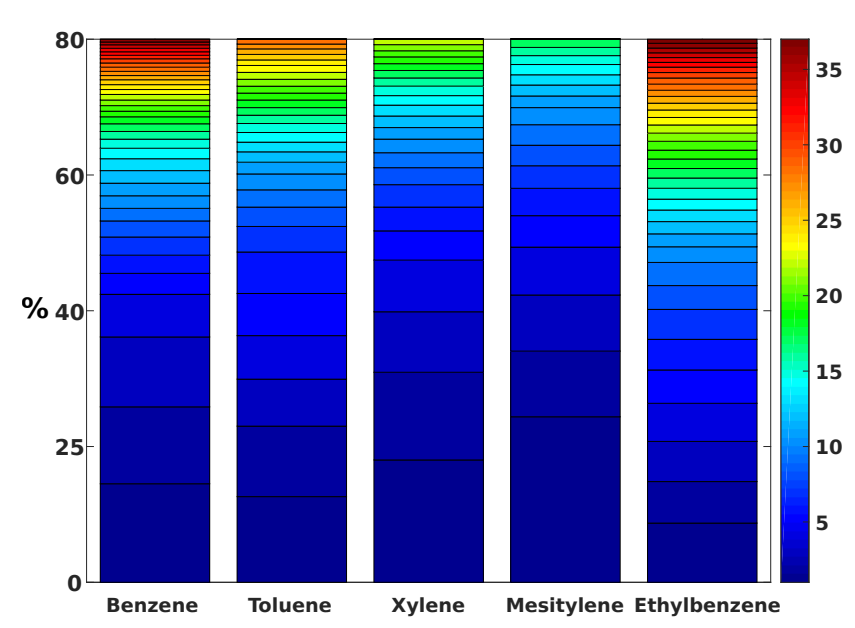

Figure 4. Graphical representation of the cumulative peak lists for the five monocyclic ArHCs. The bar plot shows the cumulative contribution of the most abundant HOM species to $80 \%$ of the total detected signal for each single-ring ArHC. Each color of the stacked bar plots denotes a certain number of cumulative compounds. In the series benzene, toluene, xylene, and mesitylene, a gradually smaller number of different HOM species is needed to explain $80 \%$ of the total signal. However, this trend with the increase in the number of substituents is not met by ethylbenzene. This may be linked to the fact that dimers with an unexpectedly low number of hydrogen were observed. Ethylbenzene shows a lower fraction of HOM • $\mathrm{NO}_{3}^{-}$adducts as well.

the Master Chemical Mechanism MCM 3.3.1 (Jenkin et al., 2003), which yields products like benzaldehyde and benzyl alcohol). For mesitylene (Fig. 5), the $\mathrm{OH}$ adduct and the first $\mathrm{RO}_{2} \cdot$ radical $\left(\mathrm{HO}-\mathrm{C}_{x} \mathrm{H}_{y} \mathrm{OO} \cdot\right.$ ) cannot be detected with the nitrate CI-APi-TOF (Hyttinen et al., 2015) and are depicted in grey in Fig. 5. More highly oxygenated $\mathrm{RO}_{2}$ - radicals with the formula $\mathrm{C}_{9} \mathrm{H}_{13} \mathrm{O}_{5-11}$ were, however, found, with the highest intensity for $\mathrm{C}_{9} \mathrm{H}_{13} \mathrm{O}_{7}$ (3\% of the sum of the identified HOMs). In addition to radicals with an odd oxygen number, radicals with an even oxygen number of molecular formula $\mathrm{C}_{x} \mathrm{H}_{y+1} \mathrm{O}_{z_{\mathrm{e}}}$ were observed (Fig. 5). These radicals are likely produced via $\mathrm{RO}_{2} \bullet+\mathrm{RO}_{2} \bullet\left(\right.$ or $\mathrm{RO}_{2} \bullet+\mathrm{HO}_{2} \bullet$ ), involving the formation of an alkoxy radical intermediate (Lightfoot et al., 1992; Mentel et al., 2015; Orlando and Tyndall, 2012; Vereecken and Peeters, 2009) according to

$$
\begin{aligned}
\mathrm{ROO} \cdot+\mathrm{R}^{\prime} \mathrm{OO} \cdot & \rightarrow \mathrm{RO} \cdot+\mathrm{R}^{\prime} \mathrm{O} \cdot+\mathrm{O}_{2} \\
& \rightarrow \mathrm{ROH}+\mathrm{R}^{\prime}{ }_{-} \mathrm{O}+\mathrm{O}_{2} \\
& \rightarrow \mathrm{ROOR}{ }^{\prime}+\mathrm{O}_{2}, \\
\mathrm{ROO} \cdot+\mathrm{HOO} \cdot & \rightarrow \mathrm{ROOH}+\mathrm{O}_{2} \\
& \rightarrow \mathrm{RO} \cdot+\cdot \mathrm{OH}+\mathrm{O}_{2} .
\end{aligned}
$$

These alkoxy radicals (Reactions R3a and R4b) may isomerize to an alcohol by internal $\mathrm{H}$ abstraction forming a carbon-centered radical, which can again take up an oxygen molecule and follow the autoxidation route. The peroxy radicals of this reaction channel have the formula $\mathrm{C}_{x} \mathrm{H}_{y+1} \mathrm{O}_{z_{\mathrm{e}}}$ (see Fig. 5). Besides the formation of alkoxy radicals, recombination can also lead to a carbonyl and alcohol species (Reaction R3b) with the formulae $\mathrm{C}_{x} \mathrm{H}_{y} \mathrm{O}_{z}$ and $\mathrm{C}_{x} \mathrm{H}_{y+2} \mathrm{O}_{z}$. The much higher intensity of the peaks with the formula $\mathrm{C}_{x} \mathrm{H}_{y+2} \mathrm{O}_{z}$ compared to those with the composition $\mathrm{C}_{x} \mathrm{H}_{y} \mathrm{O}_{z}$ can be ascribed to a high contribution from the recombination of $\mathrm{RO}_{2} \cdot$ with $\mathrm{HO}_{2} \cdot$ (Reaction $\mathrm{R} 4 \mathrm{a}$ ). This is due to the high $\mathrm{HO}_{2}$ - concentration in our experiments since $\mathrm{HO}_{2}$. is also formed in the $\mathrm{OH}$ radical source. The formation of ROOR (Reaction R3c) corresponds to $\mathrm{C}_{2 x} \mathrm{H}_{2 y+2} \mathrm{O}_{z}$ dimer formation, with $z$ being even or odd, depending on the combination of the reacting peroxy radicals. We also detected free radicals and closed-shell molecules with an unexpectedly high number of hydrogen atoms, with the formulae 


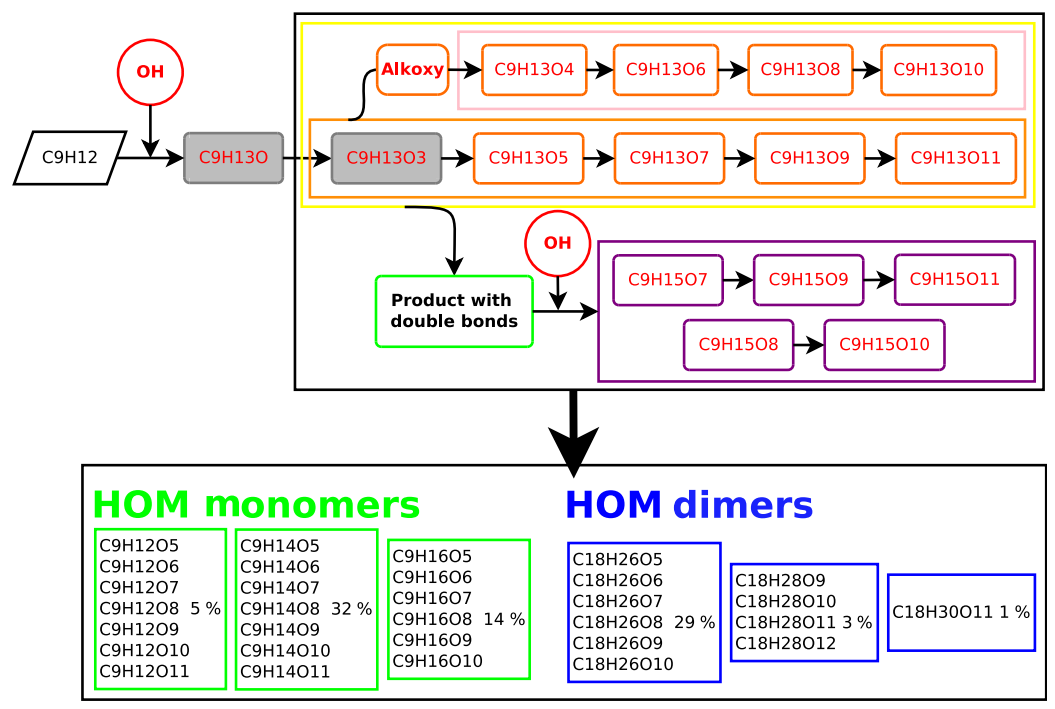

Figure 5. Proposed generalized reaction scheme of HOM formation for mesitylene (1,3,5-trimethylbenzene) after OH addition. Closed-shell species are displayed in black (even number of $\mathrm{H}$ ), radicals (odd number of $\mathrm{H}$ ) in red. Grey color denotes radicals that were not detected by the chemical ionization atmospheric pressure interface time of flight mass spectrometer. Radicals in the orange box are from the propagation of the initial $\mathrm{OH}$ attack with an odd number of oxygen atoms, radicals in the pink box are formed via an alkoxy intermediate step with an even number of oxygen atoms, and radicals in the purple box are products of a second $\mathrm{OH}$ addition. Reacting oxygen molecules along the radical propagation chain are not indicated. Closed-shell species are divided into monomers (green boxes) and dimers (blue boxes). The percentages in the boxes indicate the relative intensity of a peak to the total detected ArHC HOM signal. The sum does not add up to $100 \%$ because some peaks mainly coming from fragmentation are not included in the scheme.

$\mathrm{C}_{x} \mathrm{H}_{y+(3,5)} \mathrm{O}_{z}$ and $\mathrm{C}_{x} \mathrm{H}_{y+(4,6)} \mathrm{O}_{z}$, respectively. For mesitylene (Fig. 5), radicals with the formula $\mathrm{C}_{9} \mathrm{H}_{15} \mathrm{O}_{7-11}$ were identified, with the highest signals found for $\mathrm{C}_{9} \mathrm{H}_{15} \mathrm{O}_{7}(1 \%)$, and $\mathrm{C}_{9} \mathrm{H}_{15} \mathrm{O}_{8}(2 \%)$. These compounds are likely formed by a second $\mathrm{OH}$ addition as discussed further below. Monomer closed-shell molecules were detected as $\mathrm{C}_{9} \mathrm{H}_{12} \mathrm{O}_{5-11}(4 \%)$, $\mathrm{C}_{9} \mathrm{H}_{14} \mathrm{O}_{4-11}(25 \%)$, and $\mathrm{C}_{9} \mathrm{H}_{16} \mathrm{O}_{5-10}(12 \%)$. We assume that the $\mathrm{C}_{9} \mathrm{H}_{12} \mathrm{O}_{5-11}$ molecules derive from the first radical generation $\left(\mathrm{C}_{9} \mathrm{H}_{13} \mathrm{O}_{5-11}\right)$ and the $\mathrm{C}_{9} \mathrm{H}_{16} \mathrm{O}_{5-10}$ molecules from a second $\mathrm{OH}$ attack $\left(\mathrm{C}_{9} \mathrm{H}_{15} \mathrm{O}_{7-11}\right)$. The $\mathrm{C}_{9} \mathrm{H}_{14} \mathrm{O}_{4-11}$ molecules may be produced from either the first or the second $\mathrm{OH}$ attack. However, further investigation is required to test these hypotheses. We also want to point out that the relative signal intensities may be biased by the nitrate clustering properties and do not necessarily reflect the actual distribution of the neutral compounds. Similarly, the compounds with an $\mathrm{H}$ atom number lower than the ArHC precursor could have been formed by an $\mathrm{H}$ abstraction from first-generation products with the formula $\mathrm{C}_{x} \mathrm{H}_{y} \mathrm{O}_{z}$.

The recombination of two peroxy radicals may lead to a covalently bound peroxy-bridged dimer. We observed three classes of such products (Fig. 5): (i) from the recombination of two first-generation radicals (13 hydrogen atoms each) with the molecular formula $\mathrm{C}_{18} \mathrm{H}_{26} \mathrm{O}_{8-13}$ (30\% of the total intensity), (ii) from the recombination of a first-generation radical with a second generation radical $(13+15$ hydrogen atoms) with the formula $\mathrm{C}_{18} \mathrm{H}_{28} \mathrm{O}_{9-12}$ (3\% of the total signal), and (iii) from the recombination of two radicals from the second generation $(15+15$ hydrogen atoms), where only one compound was identified $\left(\mathrm{C}_{18} \mathrm{H}_{30} \mathrm{O}_{11}, 1 \%\right)$.

Some identified monomer and dimer peaks belong to oxygenated molecules with fewer carbon atoms than the respective precursor. This is likely the result of a fragmentation process. HOMs with fewer $\mathrm{C}$ atoms than the parent molecule have also been previously described from terpene precursors via CO elimination (Rissanen et al., 2014, 2015). Here, the aromatics mostly also show a loss of $\mathrm{H}$ atoms when fragmenting. This indicates that a methyl group can be lost after oxidation to an alkoxy radical as formaldehyde or a carbon fragment can be lost after ring cleavage. As mentioned above, we hypothesize that the $\mathrm{C}_{x} \mathrm{H}_{y+(3,5)} \mathrm{O}_{z}$ radicals and $\mathrm{C}_{x} \mathrm{H}_{y+(4,6)} \mathrm{O}_{z}$ molecules may have formed by multiple $\mathrm{OH}$ attacks in our reactor. This is possible when the second $\mathrm{OH}$ attacks a product molecule that contains two hydrogen atoms more than the parent molecule. To allow for the addition of a second $\mathrm{OH}$ free radical, these first-generation closed-shell molecules must still contain a carbon-carbon double bond in their structure. A third $\mathrm{OH}$ attack is observed only for some compounds: benzene, ethylbenzene, xylene, naphthalene, and biphenyl. The contribution of these HOMs to the total of the detected signals is always extremely low. The mechanism will likely proceed in a similar way.

An explicit mechanism after $\mathrm{OH}$ addition for a possible pathway of the aromatic autoxidation is suggested in Fig. 6 for up to seven oxygen atoms. After the addition of $\mathrm{OH}$ and the loss of aromaticity, an oxygen molecule can be added, 


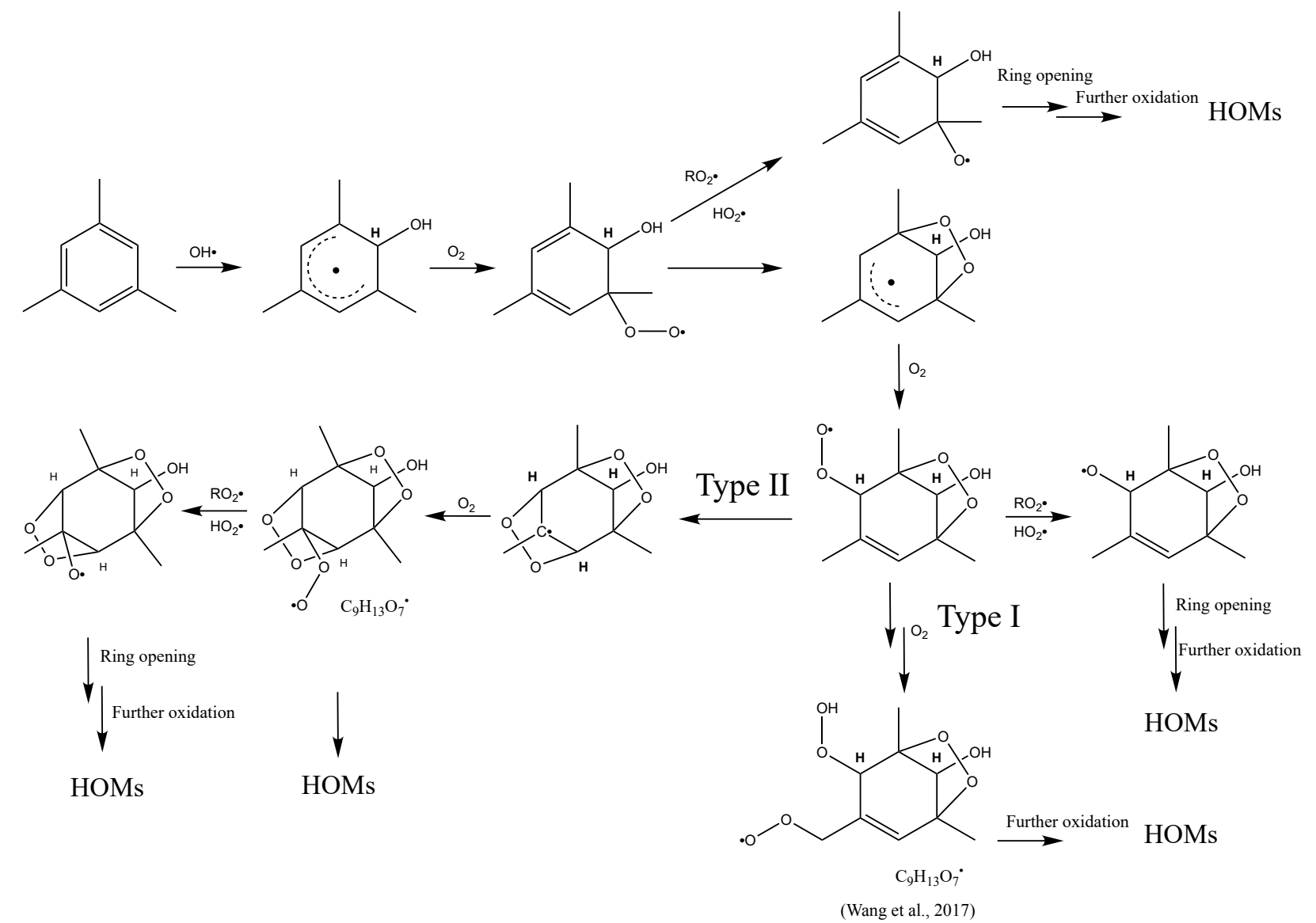

Figure 6. Proposed radical reaction mechanism for the autoxidation of mesitylene. The mechanism is derived from the MCM (version 3.3.1) up to the $\mathrm{C}_{9} \mathrm{H}_{13} \mathrm{O}_{5}$ radical. From there the Type I pathway is from Wang et al. (2017).

forming a peroxy radical. It has been established that the latter can cyclize, producing a second stabilized allylic radical with an endocyclic $\mathrm{O}_{2}$ bridge (Baltaretu et al., 2009; Birdsall and Elrod, 2011; Pan and Wang, 2014). To this oxygenbridged bicyclic radical, further oxygen additions followed by cyclization or internal $\mathrm{H}$ abstraction might occur up to a peroxy radical with seven oxygen atoms $\left(\mathrm{C}_{9} \mathrm{H}_{13} \mathrm{O}_{7}\right)$, which is the species detected at relatively high intensity $(3.5 \%)$. Two potential routes are shown in Fig. 6. One follows the traditional autoxidation mechanism with internal $\mathrm{H}$ abstraction and oxygen addition (Type I autoxidation). The other route proposes another cyclization forming a second oxygen bridge. This mechanism also produces a carbon-centered radical and promotes autoxidation (Type II) by the addition of another oxygen molecule. Wang et al. (2017) provide evidence from isotope labeling experiments for the occurrence of Type I autoxidation in isopropylbenzene. Some of the ArHC tested also form radicals with a higher number of odd oxygens (i.e., up to 9-11 O atoms; Sect. S3 in the Supplement), indicating that autoxidation may even proceed further. Compounds with an even number of oxygen are formed via the alkoxy pathway and may also include a ring open- ing step. Possible branching channels where this may happen are indicated in Fig. 6. Termination reactions to alcohols (Reaction R3b) or hydroperoxides (Reaction R4a) can form molecules still containing double bonds, which can further add an $\mathrm{OH}$ radical, leading to compounds with four hydrogen atoms more than the precursor.

As mentioned above naphthalene and biphenyl, despite the polycyclic skeleton, do not show a radically different behavior compared to the single-ring ArHCs. The maximum number of oxygen atoms that their monomer HOMs can host is 10 for naphthalene and 11 for biphenyl. Biphenyl seems to compare with its single ring analogue benzene. $\mathrm{C}_{6} \mathrm{H}_{8} \mathrm{O}_{5}$ and $\mathrm{C}_{12} \mathrm{H}_{12} \mathrm{O}_{5}$ are the strongest peaks indicating that the oxidation of one benzene ring in biphenyl proceeds in a similar way. Similarly, the strongest dimer is $\mathrm{C}_{12} \mathrm{H}_{14} \mathrm{O}_{8}$ for benzene and $\mathrm{C}_{24} \mathrm{H}_{22} \mathrm{O}_{8}$ for biphenyl. Compounds with extra-high $\mathrm{H}$ atoms are more frequently found for biphenyl, which is expected as there is a second reactive aromatic ring remaining after (auto)-oxidation of the first one. Thus, a second $\mathrm{OH}$ attack is probable. Naphthalene seems to take up less oxygen than the other compounds, showing the maximum signal intensity at four to five oxygen atoms for monomers and only 
four to six for dimers. This may indicate that it is not possible for both rings to be easily autoxidized in one step. It is also interesting to note that compounds from a second $\mathrm{OH}$ attack do not show a strong increase in the oxygen content, neither for the single- nor for the double-ring ArHCs.

\section{Conclusions and atmospheric implications}

All tested compounds yielded HOMs, and we conclude that this is a common feature of aromatic compounds. Similar to the oxidation process that yields HOMs from terpenes, the oxidation process of ArHC yields highly oxygenated compounds containing the carbon skeleton of the precursor (monomers) as well as twice as many carbons (dimers). It is known from previous studies that ArHC are able to add molecular oxygen to the molecule after $\mathrm{OH}$ addition forming an oxygen-bridged bicyclic radical. Our measurements of highly oxygenated compounds with up to 11 oxygen atoms in a monomer reveal that an autoxidation radical chain reaction occurs by adding several more oxygens to the initially formed radical. The autoxidation radical chain reaction is thought to proceed via the intramolecular abstraction of a hydrogen atom from an acidic $\mathrm{C}-\mathrm{H}$ bond by a peroxy radical and the consequent formation of a hydroperoxy functional group and a carbon-centered radical that can take up an oxygen molecule from the surroundings and eventually repeat the whole process $n$ times (Type I autoxidation). In the case of aromatic compounds, when the aromaticity is destroyed, Type II autoxidation may happen by further addition of oxygen to the allylic resonance-stabilized radical followed by an attack of the peroxy group on the internal double bonds forming an oxygen bridge. This can proceed up to a peroxy radical of seven oxygen. Type II autoxidation has also been proposed to occur with sesquiterpenes with two double bonds (Richters et al., 2016) and also with $\alpha$-pinene for certain HOMs (Rissanen et al., 2015). Even though the autoxidation of ArHCs will lead to different chemical compounds compared to HOMs from terpenes, we expect similar chemical and physical characteristics such as functional groups and volatility. In both cases extremely low-volatility, highly oxygenated dimer species are formed, which may play an important role in new particle formation.

Recent studies (Nakao et al., 2011; Schwantes et al., 2017) suggest that from hydroxy ArHC equivalents, which are formed in the first-generation $\mathrm{OH}$ oxidation of aromatics, additional $\mathrm{OH}$ oxidation steps can produce substantial amounts of polyhydroxy aromatics with a high $\mathrm{O}: \mathrm{C}$ ratio (up to 1.2). However, literature data show varying yields for the conversion of arenes to phenols via the $\mathrm{OH}$ radical addition and $\mathrm{H}$ elimination. According to MCM 3.3.1 (Jenkin et al., 2003), benzene and toluene have quite high phenol yields (approximately 50 and $20 \%$, respectively), while mesitylene shows a rather small yield $(4 \%)$. This fact should be reflected in the final HOM yield with alkyl-substituted ArHCs being less ef- fective in yielding HOMs. However, in our experiments we did not detect such a difference in the HOM yields linked to phenol formation yields. A substantial fraction of the detected HOMs showed a hydrogen atom number higher than the precursor ArHC which cannot be explained with the presence of just polyphenolic compounds as oxidation products.

Quantum chemical calculations have revealed that intramolecular $\mathrm{H}$ migrations in bicyclic peroxy radicals may be a feasible route to HOMs (Wang et al., 2017). In particular, aromatics with a longer-chain substituent (ethyl-, isopropylbenzene) or multiple substituents may have a fast HOM formation pathway. Indeed, our measurements show somewhat higher HOM yields for xylene and mesitylene compared to benzene and toluene. However, more kinetic and mechanistic studies are needed to better understand HOM formation from the various aromatics.

Under urban conditions, in the presence of NO, the reaction of $\mathrm{RO}_{2} \cdot+\mathrm{NO}$ will compete with the autoxidation pathway. This can lead to relatively highly oxygenated nitrates of low volatility or oxyradicals. The latter can isomerize to a carbon-centered radical as under our conditions and again undergo autoxidation. Highly oxygenated organic nitrates have been recently identified in SOA (Lee et al., 2016). While this study shows that autoxidation can also occur after an $\mathrm{OH}$ attack of ArHC, the formation of low-volatility products via this route in the presence of NO, which is typical of urban atmospheres, needs further investigation. Furthermore, first-generation oxidation products may still contain carbon-carbon double bonds, which could also further react with ozone, forming more highly oxygenated products. Since the reaction time is very short in the flow tube this reaction is negligible but could be another potential pathway in the ambient atmosphere.

Some of the HOMs measured here from the oxidation of ArHC have the same composition as the HOMs formulae identified by Bianchi et al. (2016) during wintertime nucleation episodes at the Jungfraujoch High Altitude Research Station.

The fact that the oxidation of ArHC can rapidly form HOMs of very low-volatility makes ArHC a potential contributor to nucleation and early particle growth during nucleation episodes observed in urban areas (Stanier et al., 2004; Wang et al., 2015; Xiao et al., 2015; Yu et al., 2016).

Data availability. Data related to this article are available online at https://doi.org/10.5281/zenodo.1164436 (Molteni and Urs, 2018).

The Supplement related to this article is available online at https://doi.org/10.5194/acp-18-1909-2018-supplement. 
Competing interests. The authors declare that they have no conflict of interest.

Acknowledgements. We thank Markus Ammann for the laboratory equipment, Dogushan Kilic for technical support, and Simone Maria Pieber and Christopher Robert Hoyle for scientific discussions and comments on the manuscript. The tofTools team is acknowledged for providing tools for mass spectrometry analysis. This work was supported by the Swiss National Science Foundation (20020_152907/1, 20020_172602, P2EZP2_168787).

Edited by: Sergey A. Nizkorodov

Reviewed by: three anonymous referees

\section{References}

Atkinson, R. and Arey, J.: Atmospheric degradation of volatile organic compounds, Chem. Rev., 103, 4605-4638, https://doi.org/10.1021/cr0206420, 2003.

Baltaretu, C. O., Lichtman, E. I., Hadler, A. B., and Elrod, M. J.: Primary atmospheric oxidation mechanism for toluene, J. Phys. Chem. A, 113, 221-230, https://doi.org/10.1021/jp806841t, 2009.

Barmet, P., Dommen, J., DeCarlo, P. F., Tritscher, T., Praplan, A. P., Platt, S. M., Prévôt, A. S. H., Donahue, N. M., and Baltensperger, $\mathrm{U}$.: $\mathrm{OH}$ clock determination by proton transfer reaction mass spectrometry at an environmental chamber, Atmos. Meas. Tech., 5, 647-656, https://doi.org/10.5194/amt-5-647-2012, 2012.

Bartels-Rausch, T., Ulrich, T., Huthwelker, T., and Ammann, M.: A novel synthesis of the $\mathrm{N}-13$ labeled atmospheric trace gas peroxynitric acid, Radiochim. Acta, 99, 285-292, https://doi.org/10.1524/ract.2011.1830, 2011.

Berndt, T., Richters, S., Kaethner, R., Voigtländer, J., Stratmann, F., Sipilä, M., Kulmala, M., and Herrmann, H.: Gasphase ozonolysis of cycloalkenes: formation of highly oxidized $\mathrm{RO}_{2}$ radicals and their reactions with $\mathrm{NO}, \mathrm{NO}_{2}, \mathrm{SO}_{2}$ and other $\mathrm{RO}_{2}$ radicals, J. Phys. Chem. A, 119, 10336-10348, https://doi.org/10.1021/acs.jpca.5b07295, 2015.

Bianchi, F., Trostl, J., Junninen, H., Frege, C., Henne, S., Hoyle, C. R., Molteni, U., Herrmann, E., Adamov, A., Bukowiecki, N., Chen, X., Duplissy, J., Gysel, M., Hutterli, M., Kangasluoma, J., Kontkanen, J., Kürten, A., Manninen, H. E., Münch, S., Peräkylä, O., Petäjä, T., Rondo, L., Williamson, C., Weingartner, E., Curtius, J., Worsnop, D. R., Kulmala, M., Dommen, J., and Baltensperger, U.: New particle formation in the free troposphere: A question of chemistry and timing, Science, 352, 1109-1112, https://doi.org/10.1126/science.aad5456, 2016.

Birdsall, A. W. and Elrod, M. J.: Comprehensive NO-dependent study of the products of the oxidation of atmospherically relevant aromatic compounds, J. Phys. Chem. A, 115, 5397-5407, https://doi.org/10.1021/jp2010327, 2011.

Bohn, B.: Formation of peroxy radicals from $\mathrm{OH}-$ toluene adducts and $\mathrm{O}_{2}$, J. Phys. Chem. A, 105, 6092-6101, https://doi.org/10.1021/jp0033972, 2001.

Bruns, E. A., El Haddad, I., Slowik, J. G., Kilic, D., Klein, F., Baltensperger, U., and Prévôt, A. S. H.: Identification of significant precursor gases of secondary organic aerosols from residential wood combustion, Sci. Rep., 6, 27881, https://doi.org/10.1038/srep27881, 2016.

Calvert, J. G., Atkinson, R., Becker, K. H., Kamens, R. M., Seinfeld, J. H., Wallington, T. H., and Yarwood, G.: The mechanisms of atmospheric oxidation of the aromatic hydrocarbons, Oxford University Press, 2002.

Carslaw, K. S., Lee, L. A., Reddington, C. L., Pringle, K. J., Rap, A., Forster, P. M., Mann, G. W., Spracklen, D. V, Woodhouse, M. T., Regayre, L., and Pierce, J. R.: Large contribution of natural aerosols to uncertainty in indirect forcing, Nature, 503, 67-71, https://doi.org/10.1038/nature12674, 2013.

Crounse, J. D., Knap, H. C., Ørnsø, K. B., Jørgensen, S., Paulot, F., Kjaergaard, H. G., and Wennberg, P. O.: Atmospheric fate of methacrolein. 1. peroxy radical isomerization following addition of $\mathrm{OH}$ and $\mathrm{O}_{2}$, J. Phys. Chem. A, 116, 5756-5762, https://doi.org/10.1021/jp211560u, 2012.

Crounse, J. D., Nielsen, L. B., Jørgensen, S., Kjaergaard, H. G., and Wennberg, P. O.: Autoxidation of organic compounds in the atmosphere, J. Phys. Chem. Lett., 4, 3513-3520, https://doi.org/10.1021/jz4019207, 2013.

Donahue, N. M., Ortega, I. K., Chuang, W., Riipinen, I., Riccobono, F., Schobesberger, S., Dommen, J., Baltensperger, U., Kulmala, M., Worsnop, D. R., and Vehkamaki, H.: How do organic vapors contribute to new-particle formation?, Faraday Discuss., 165, 91-104, https://doi.org/10.1039/c3fd00046j, 2013.

Ehn, M., Thornton, J. a., Kleist, E., Sipilä, M., Junninen, H., Pullinen, I., Springer, M., Rubach, F., Tillmann, R., Lee, B., Lopez-Hilfiker, F., Andres, S., Acir, I.-H., Rissanen, M., Jokinen, T., Schobesberger, S., Kangasluoma, J., Kontkanen, J., Nieminen, T., Kurtén, T., Nielsen, L. B., Jørgensen, S., Kjaergaard, H. G., Canagaratna, M., Maso, M. D., Berndt, T., Petäjä, T., Wahner, A., Kerminen, V.-M., Kulmala, M., Worsnop, D. R., Wildt, J., and Mentel, T. F.: A large source of lowvolatility secondary organic aerosol, Nature, 506, 476-479, https://doi.org/10.1038/nature13032, 2014.

Glowacki, D. R. and Pilling, M. J.: Unimolecular reactions of peroxy radicals in atmospheric chemistry and combustion, Chem. Phys. Chem., 11, 3836-3843, https://doi.org/10.1002/cphc.201000469, 2010.

Gordon, H., Sengupta, K., Rap, A., Duplissy, J., Frege, C., Williamson, C., Heinritzi, M., Simon, M., Yan, C., Almeida, J., Tröstl, J., Nieminen, T., Ortega, I. K., Wagner, R., Dunne, E. M., Adamov, A., Amorim, A., Bernhammer, A.-K., Bianchi, F., Breitenlechner, M., Brilke, S., Chen, X., Craven, J. S., Dias, A., Ehrhart, S., Fischer, L., Flagan, R. C., Franchin, A., Fuchs, C., Guida, R., Hakala, J., Hoyle, C. R., Jokinen, T., Junninen, H., Kangasluoma, J., Kim, J., Kirkby, J., Krapf, M., Kürten, A., Laaksonen, A., Lehtipalo, K., Makhmutov, V., Mathot, S., Molteni, U., Monks, S. A., Onnela, A., Peräkylä, O., Piel, F., Petäjä, T., Praplan, A. P., Pringle, K. J., Richards, N. A. D., Rissanen, M. P., Rondo, L., Sarnela, N., Schobesberger, S., Scott, C. E., Seinfeld, J. H., Sharma, S., Sipilä, M., Steiner, G., Stozhkov, Y., Stratmann, F., Tomé, A., Virtanen, A., Vogel, A. L., Wagner, A. C., Wagner, P. E., Weingartner, E., Wimmer, D., Winkler, P. M., Ye, P., Zhang, X., Hansel, A., Dommen, J., Donahue, N. M., Worsnop, D. R., Baltensperger, U., Kulmala, M., Curtius, J., and Carslaw, K. S.: Reduced anthropogenic aerosol radiative forcing caused by biogenic new par- 
ticle formation, P. Natl. Acad. Sci. USA, 113, 12053-12058, https://doi.org/10.1073/pnas.1602360113, 2016.

Hyttinen, N., Kupiainen-Määttä, O., Rissanen, M. P., Muuronen, M., Ehn, M., and Kurtén, T.: Modeling the charging of highly oxidized cyclohexene ozonolysis products using nitratebased chemical ionization, J. Phys. Chem. A, 119, 6339-6345, https://doi.org/10.1021/acs.jpca.5b01818, 2015.

Jain, C., Morajkar, P., Schoemaecker, C., and Fittschen, C.: Formation of $\mathrm{HO}_{2}$ radicals from the $248 \mathrm{~nm}$ two-photon excitation of different aromatic hydrocarbons in the presence of $\mathrm{O}_{2}$, J. Phys. Chem. A, 116, 6231-6239, https://doi.org/10.1021/jp211520g, 2012.

Jenkin, M. E., Saunders, S. M., Wagner, V., and Pilling, M. J.: Protocol for the development of the Master Chemical Mechanism, MCM v3 (Part B): tropospheric degradation of aromatic volatile organic compounds, Atmos. Chem. Phys., 3, 181-193, https://doi.org/10.5194/acp-3-181-2003, 2003.

Jokinen, T., Sipilä, M., Junninen, H., Ehn, M., Lönn, G., Hakala, J., Petäjä, T., Mauldin III, R. L., Kulmala, M., and Worsnop, D. R.: Atmospheric sulphuric acid and neutral cluster measurements using CI-APi-TOF, Atmos. Chem. Phys., 12, 4117-4125, https://doi.org/10.5194/acp-12-4117-2012, 2012.

Jokinen, T., Sipilä, M., Richters, S., Kerminen, V.-M., Paasonen, P., Stratmann, F., Worsnop, D., Kulmala, M., Ehn, M., Herrmann, H., and Berndt, T.: Rapid autoxidation forms highly oxidized $\mathrm{RO}_{2}$ radicals in the atmosphere, Angew. Chemie Int. Edit., 53, 14596-14600, https://doi.org/10.1002/anie.201408566, 2014.

Jokinen, T., Berndt, T., Makkonen, R., Kerminen, V., Junninen, H., Paasonen, P., Stratmann, F., Herrmann, H., Guenther, A. B., Worsnop, D. R., Kulmala, M., Ehn, M., and Sipilä, M.: Production of extremely low volatile organic compounds from biogenic emissions: Measured yields and atmospheric implications, P. Natl. Acad. Sci. USA, 112, 7123-7128, https://doi.org/10.1073/pnas.1423977112, 2015.

Jordan, A., Haidacher, S., Hanel, G., Hartungen, E., Märk, L., Seehauser, H., Schottkowsky, R., Sulzer, P., and Märk, T. D.: A high resolution and high sensitivity proton-transfer-reaction time-offlight mass spectrometer (PTR-TOF-MS), Int. J. Mass Spectrom., 286, 122-128, https://doi.org/10.1016/j.ijms.2009.07.005, 2009.

Kirkby, J., Duplissy, J., Sengupta, K., Frege, C., Gordon, H., Williamson, C., Heinritzi, M., Simon, M., Yan, C., Almeida, J., Tröstl, J., Nieminen, T., Ortega, I. K., Wagner, R., Adamov, A., Amorim, A., Bernhammer, A.-K., Bianchi, F., Breitenlechner, M., Brilke, S., Chen, X., Craven, J., Dias, A., Ehrhart, S., Flagan, R. C., Franchin, A., Fuchs, C., Guida, R., Hakala, J., Hoyle, C. R., Jokinen, T., Junninen, H., Kangasluoma, J., Kim, J., Krapf, M., Kürten, A., Laaksonen, A., Lehtipalo, K., Makhmutov, V., Mathot, S., Molteni, U., Onnela, A., Peräkylä, O., Piel, F., Petäjä, T., Praplan, A. P., Pringle, K., Rap, A., Richards, N. A. D., Riipinen, I., Rissanen, M. P., Rondo, L., Sarnela, N., Schobesberger, S., Scott, C. E., Seinfeld, J. H., Sipilä, M., Steiner, G., Stozhkov, Y., Stratmann, F., Tomé, A., Virtanen, A., Vogel, A. L., Wagner, A. C., Wagner, P. E., Weingartner, E., Wimmer, D., Winkler, P. M., Ye, P., Zhang, X., Hansel, A., Dommen, J., Donahue, N. M., Worsnop, D. R., Baltensperger, U., Kulmala, M., Carslaw, K. S., and Curtius, J.: Ion-induced nucleation of pure biogenic particles, Nature, 533, 521-526, https://doi.org/10.1038/nature17953, 2016.
Kogelschatz, U.: Silent discharges for the generation of ultraviolet and vacuum ultraviolet excimer radiation, Pure Appl. Chem., 62, 1667-1674, https://doi.org/10.1351/pac199062091667, 1990.

Kogelschatz, U.: Ultraviolet excimer radiation from nonequilibrium gas discharges and its application in photophysics, photochemistry and photobiology, J. Opt. Technol., 79, 484-493, https://doi.org/10.1364/JOT.79.000484, 2012.

Kulmala, M., Kontkanen, J., Junninen, H., Lehtipalo, K., Manninen, H. E., Nieminen, T., Petaja, T., Sipila, M., Schobesberger, S., Rantala, P., Franchin, A., Jokinen, T., Jarvinen, E., Aijala, M., Kangasluoma, J., Hakala, J., Aalto, P. P., Paasonen, P., Mikkila, J., Vanhanen, J., Aalto, J., Hakola, H., Makkonen, U., Ruuskanen, T., Mauldin, R. L., Duplissy, J., Vehkamaki, H., Back, J., Kortelainen, A., Riipinen, I., Kurten, T., Johnston, M. V, Smith, J. N., Ehn, M., Mentel, T. F., Lehtinen, K. E. J., Laaksonen, A., Kerminen, V.-M., and Worsnop, D. R.: Direct observations of atmospheric aerosol nucleation, Science, 339, 943-946, https://doi.org/10.1126/science.1227385, 2013.

Kürten, A., Rondo, L., Ehrhart, S., and Curtius, J.: Performance of a corona ion source for measurement of sulfuric acid by chemical ionization mass spectrometry, Atmos. Meas. Tech., 4, 437-443, https://doi.org/10.5194/amt-4-437-2011, 2011.

Kurtén, T., Rissanen, M. P., Mackeprang, K., Thornton, J. A., Hyttinen, N., Jørgensen, S., Ehn, M., and Kjaergaard, H. G.: Computational study of hydrogen shifts and ring-opening mechanisms in $\alpha$-pinene ozonolysis products, J. Phys. Chem. A, 119, 1136611375, https://doi.org/10.1021/acs.jpca.5b08948, 2015.

Lee, B. H., Mohr, C., Lopez-Hilfiker, F. D., Lutz, A., Hallquist, M., Lee, L., Romer, P., Cohen, R. C., Iyer, S., Kurtén, T., Hu, W., Day, D. A., Campuzano-Jost, P., Jimenez, J. L., Xu, L., Ng, N. L., Guo, H., Weber, R. J., Wild, R. J., Brown, S. S., Koss, A., de Gouw, J., Olson, K., Goldstein, A. H., Seco, R., Kim, S., McAvey, K., Shepson, P. B., Starn, T., Baumann, K., Edgerton, E. S., Liu, J., Shilling, J. E., Miller, D. O., Brune, W., Schobesberger, S., D'Ambro, E. L., and Thornton, J. A.: Highly functionalized organic nitrates in the southeast United States: Contribution to secondary organic aerosol and reactive nitrogen budgets, P. Natl. Acad. Sci. USA, 113, 1516-1521, https://doi.org/10.1073/pnas.1508108113, 2016.

Li, L., Tang, P., Nakao, S., Kacarab, M., and Cocker, D. R.: Novel approach for evaluating secondary organic aerosol from aromatic hydrocarbons: unified method for predicting aerosol composition and formation, Environ. Sci. Technol., 50, 6249-6256, https://doi.org/10.1021/acs.est.5b05778, 2016.

Lightfoot, P., Cox, R., Crowley, J., Destriau, M., Hayman, G., Jenkin, M., Moortgat, G., and Zabel, F.: Organic peroxy radicals: kinetics, spectroscopy and tropospheric chemistry, Atmos. Environ. A-Gen., 26, 1805-1961, https://doi.org/10.1016/09601686(92)90423-I, 1992.

Mentel, T. F., Springer, M., Ehn, M., Kleist, E., Pullinen, I., Kurtén, T., Rissanen, M., Wahner, A., and Wildt, J.: Formation of highly oxidized multifunctional compounds: autoxidation of peroxy radicals formed in the ozonolysis of alkenes - deduced from structure-product relationships, Atmos. Chem. Phys., 15, 67456765, https://doi.org/10.5194/acp-15-6745-2015, 2015.

Metzger, A., Verheggen, B., Dommen, J., Duplissy, J., Prevot, A. S. H., Weingartner, E., Riipinen, I., Kulmala, M., Spracklen, D. V, Carslaw, K. S., and Baltensperger, U.: Evidence for the role of organics in aerosol particle formation under atmo- 
spheric conditions, P. Natl. Acad. Sci. USA, 107, 6646-6651, https://doi.org/10.1073/pnas.0911330107, 2010.

Molina, M. J., Zhang, R., Broekhuizen, K., Lei, W., Navarro, R., and Molina, L. T.: Experimental study of intermediates from $\mathrm{OH}-$ initiated reactions of toluene, J. Am. Chem. Soc., 121, 1022510226, https://doi.org/10.1021/ja992461u, 1999.

Molteni, U. and Baltensperger, U.: Formation of highly oxygenated organic molecules from aromatic compounds, Zenodo, https://doi.org/10.5281/zenodo.1164436, 2018.

Nakao, S., Clark, C., Tang, P., Sato, K., and Cocker III, D.: Secondary organic aerosol formation from phenolic compounds in the absence of $\mathrm{NO}_{x}$, Atmos. Chem. Phys., 11, 10649-10660, https://doi.org/10.5194/acp-11-10649-2011, 2011.

Orlando, J. J. and Tyndall, G. S.: Laboratory studies of organic peroxy radical chemistry: an overview with emphasis on recent issues of atmospheric significance, Chem. Soc. Rev., 41, 6294, https://doi.org/10.1039/c2cs35166h, 2012.

Pan, S. and Wang, L.: Atmospheric oxidation mechanism of mxylene initiated by OH radical, J. Phys. Chem. A, 118, 1077810787, https://doi.org/10.1021/jp506815v, 2014.

Peng, Z., Day, D. A., Ortega, A. M., Palm, B. B., Hu, W., Stark, H., Li, R., Tsigaridis, K., Brune, W. H., and Jimenez, J. L.: Non-OH chemistry in oxidation flow reactors for the study of atmospheric chemistry systematically examined by modeling, Atmos. Chem. Phys., 16, 4283-4305, https://doi.org/10.5194/acp16-4283-2016, 2016.

Praplan, A. P., Schobesberger, S., Bianchi, F., Rissanen, M. P., Ehn, M., Jokinen, T., Junninen, H., Adamov, A., Amorim, A., Dommen, J., Duplissy, J., Hakala, J., Hansel, A., Heinritzi, M., Kangasluoma, J., Kirkby, J., Krapf, M., Kürten, A., Lehtipalo, K., Riccobono, F., Rondo, L., Sarnela, N., Simon, M., Tomé, A., Tröstl, J., Winkler, P. M., Williamson, C., Ye, P., Curtius, J., Baltensperger, U., Donahue, N. M., Kulmala, M., and Worsnop, D. R.: Elemental composition and clustering behaviour of $\alpha$ pinene oxidation products for different oxidation conditions, Atmos. Chem. Phys., 15, 4145-4159, https://doi.org/10.5194/acp15-4145-2015, 2015.

Pratte, P. and Rossi, M. J.: The heterogeneous kinetics of $\mathrm{HOBr}$ and $\mathrm{HOCl}$ on acidified sea salt and model aerosol at 40-90\% relative humidity and ambient temperature, Phys. Chem. Chem. Phys., 8, 3988-4001, https://doi.org/10.1039/B604321F, 2006.

Richters, S., Herrmann, H., and Berndt, T.: Highly oxidized $\mathrm{RO}_{2}$ radicals and consecutive products from the ozonolysis of three sesquiterpenes, Environ. Sci. Technol., 50, 2354-2362, https://doi.org/10.1021/acs.est.5b05321, 2016.

Rissanen, M. P., Kurtén, T., Sipilä, M., Thornton, J. A., Kangasluoma, J., Sarnela, N., Junninen, H., Jørgensen, S., Schallhart, S., Kajos, M. K., Taipale, R., Springer, M., Mentel, T. F., Ruuskanen, T., Petäjä, T., Worsnop, D. R., Kjaergaard, H. G., and Ehn, M.: The formation of highly oxidized multifunctional products in the ozonolysis of cyclohexene, J. Am. Chem. Soc., 136, 1559615606, https://doi.org/10.1021/ja507146s, 2014.

Rissanen, M. P., Kurtén, T., Sipilä, M., Thornton, J. A., Kausiala, O., Garmash, O., Kjaergaard, H. G., Petäjä, T., Worsnop, D. R., Ehn, M., and Kulmala, M.: Effects of chemical complexity on the autoxidation mechanisms of endocyclic alkene ozonolysis products: from methylcyclohexenes toward understanding $\alpha$-pinene, J. Phys. Chem. A, 119, 4633-4650, https://doi.org/10.1021/jp510966g, 2015.
Salvermoser, M., Murnick, D. E., and Kogelschatz, U.: Influence of water vapor on photochemical ozone generation with efficient $172 \mathrm{~nm}$ xenon excimer lamps, Ozone Sci. Eng., 30, 228-237, https://doi.org/10.1080/01919510802070611, 2008.

Schwantes, R. H., Schilling, K. A., McVay, R. C., Lignell, H., Coggon, M. M., Zhang, X., Wennberg, P. O., and Seinfeld, J. H.: Formation of highly oxygenated low-volatility products from cresol oxidation, Atmos. Chem. Phys., 17, 3453-3474, https://doi.org/10.5194/acp-17-3453-2017, 2017.

Stanier, C. O., Khlystov, A. Y., and Pandis, S. N.: Nucleation events during the Pittsburgh air quality study: description and relation to key meteorological, gas phase, and aerosol parameters. Special Issue of Aerosol Science and Technology on Findings from the Fine Particulate Matter Supersites Program, Aerosol Sci. Tech., 38, 253-264, https://doi.org/10.1080/02786820390229570, 2004.

Suh, I., Zhang, R., Molina, L. T., and Molina, M. J.: Oxidation mechanism of aromatic peroxy and bicyclic radicals from OH-toluene reactions, J. Am. Chem. Soc., 125, 12655-12665, https://doi.org/10.1021/ja0350280, 2003.

Tröstl, J., Chuang, W. K., Gordon, H., Heinritzi, M., Yan, C., Molteni, U., Ahlm, L., Frege, C., Bianchi, F., Wagner, R., Simon, M., Lehtipalo, K., Williamson, C., Craven, J. S., Duplissy, J., Adamov, A., Almeida, J., Bernhammer, A.-K., Breitenlechner, M., Brilke, S., Dias, A., Ehrhart, S., Flagan, R. C., Franchin, A., Fuchs, C., Guida, R., Gysel, M., Hansel, A., Hoyle, C. R., Jokinen, T., Junninen, H., Kangasluoma, J., Keskinen, H., Kim, J., Krapf, M., Kürten, A., Laaksonen, A., Lawler, M., Leiminger, M., Mathot, S., Möhler, O., Nieminen, T., Onnela, A., Petäjä, T., Piel, F. M., Miettinen, P., Rissanen, M. P., Rondo, L., Sarnela, N., Schobesberger, S., Sengupta, K., Sipilä, M., Smith, J. N., Steiner, G., Tomè, A., Virtanen, A., Wagner, A. C., Weingartner, E., Wimmer, D., Winkler, P. M., Ye, P., Carslaw, K. S., Curtius, J., Dommen, J., Kirkby, J., Kulmala, M., Riipinen, I., Worsnop, D. R., Donahue, N. M., and Baltensperger, U.: The role of low-volatility organic compounds in initial particle growth in the atmosphere, Nature, 533, 527-531, https://doi.org/10.1038/nature18271, 2016.

Vereecken, L. and Peeters, J.: Decomposition of substituted alkoxy radicals-part I: a generalized structure-activity relationship for reaction barrier heights, Phys. Chem. Chem. Phys., 11, 90629074, https://doi.org/10.1039/b909712k, 2009.

Wallington, T. J., Dagaut, P., and Kurylo, M. J.: UV absorption cross sections and reaction kinetics and mechanisms for peroxy radicals in the gas phase, Chem. Rev., 92, 667-710, https://doi.org/10.1021/cr00012a008, 1992.

Wang, S., Wu, R., Berndt, T., Ehn, M., and Wang, L.: Formation of highly oxidized radicals and multifunctional products from the atmospheric oxidation of alkylbenzenes, Environ. Sci. Technol., 51, 8442-8449, https://doi.org/10.1021/acs.est.7b02374, 2017.

Wang, Z. B., Hu, M., Pei, X. Y., Zhang, R. Y., Paasonen, P., Zheng, J., Yue, D. L., Wu, Z. J., Boy, M., and Wiedensohler, A.: Connection of organics to atmospheric new particle formation and growth at an urban site of Beijing, Atmos. Environ., 103, 7-17, https://doi.org/10.1016/j.atmosenv.2014.11.069, 2015.

Xiao, S., Wang, M. Y., Yao, L., Kulmala, M., Zhou, B., Yang, X., Chen, J. M., Wang, D. F., Fu, Q. Y., Worsnop, D. R., and Wang, L.: Strong atmospheric new particle formation in winter 
in urban Shanghai, China, Atmos. Chem. Phys., 15, 1769-1781, https://doi.org/10.5194/acp-15-1769-2015, 2015.

Yu, H., Zhou, L., Dai, L., Shen, W., Dai, W., Zheng, J., Ma, Y., and Chen, M.: Nucleation and growth of sub-3 nm particles in the polluted urban atmosphere of a megacity in China, Atmos. Chem. Phys., 16, 2641-2657, https://doi.org/10.5194/acp16-2641-2016, 2016. 